\title{
Kajian Aroma Sebagai Salah Satu Pertimbangan Desain Ruang Huni Studi Kasus Cluster Naraya BSB Semarang
}

\author{
Christian Moniaga \\ Program Studi Arsitektur, Fakultas Arsitektur dan Desain, \\ Universitas Katolik Soegijapranata \\ christianmoniaga@unika.ac.id
}

\begin{abstract}
Kajian tentang bentuk, warna, material, dan tekstur sudah sering dijumpai dalam berbagai rujukan yang membahas tentang desain ruang huni. Namun dalam mendapatkan sebuah kualitas fungsi ruang yang maksimal terdapat aroma yang semestinya menjadi salah satu nilai yang penting untuk diperhatikan. BSB (Bukit Semarang Baru) di Kota Semarang merupakan sebuah kawasan pengembangan baru yang di dalamnya terdapat rancangan arsitektural hunian kontemporer. Bagaimana kajian aroma dipertimbangkan di dalam pengembangan hunian kontemporer inilah yang menjadi latar belakang penulisan penelitian ini. Metode penelitian yang digunakan adalah studi kualitatif dengan pendekatan observasi, wawancara, dan literatur. Adapun yang menjadi tujuan akhir dari penelitian ini adalah untuk melihat sejauh mana aroma menjadi pertimbangan desain ruang huni dalam hunian kontemporer untuk mendukung terciptanya fungsi bangunan secara maksimal.
\end{abstract}

Kata kunci: aroma, ruang huni, kontemporer, BSB Semarang

\section{Study of Aroma as One of the Factors for Living Room Design Case Study of the Naraya BSB Cluster in Semarang}

Studies of shapes, colors, materials, and textures have often been found in various references that discuss the design of the living room. But in getting a maximum quality function space, aroma should be one of the important factors to pay attention to. BSB (Bukit Semarang Baru) in Semarang City is a new area in which there are contemporary residential architectural designs. How the study of aroma is considered in the development of contemporary housing is the background of this research writing. The research method used is a qualitative study with an observation, interview, and literature approach. The final goal of this research is to see the extent to which aroma is a factor in designing the living space in contemporary housing to support the creation of building functions to the fullest.

Keywords: aroma, living space, contemporary, BSB Semarang

Proses Review : 1 - 20 Agustus 2019, Dinyatakan Lolos: 22 Agustus 2019 


\section{PENDAHULUAN}

Dalam sebuah perumusan desain arsitektural khususnya hunian terdapat beberapa pertimbangan yang digunakan. Pertimbangan bentuk, warna, tekstur hingga aspek yang lain yang tidak sejalur dengan disiplin ilmu arsitektur seperti aspek psikologis kerap digunakan sebagai bahan pertimbangan desain.

Manusia sebagai makhluk yang memiliki panca indera pada dasarnya bisa dijadikan pertimbangan sebagai salah satu dasar untuk mencetuskan pertimbangan desain dari sudut pandang lain. Juhani Pallasmaa dalam bukunya The Eyes of The Skin mengungkapkan bagaimana peranan dan pentingnya kelima indera yang dimiliki manusia dalam membangun sebuah paradigma tentang karya arsitektur.

Dalam penelitian ini, dengan dasar teori GAIA akan mencoba melihat bagaimana peranan kajian aroma (indera penciuman) dalam perumusan sebuah desain hunian kontemporer.

Disiplin ilmu arsitektur kerap diartikan sebagai ilmu yang berpijak pada aspek visual semata. Namun dibalik itu, sudah menjadi sebuah keharusan dalam merumuskan desain hunian, desain tersebut dapat mengakomodasi aktivitas dengan baik. Maka dari itu dalam menghasilkan sebuah desain yang baik, semestinya tetap memperhatikan kelima panca indera manusia. Kajian tentang aroma (indera penciuman) akan digunakan sebagai tolok ukur dalam menilai sebuah desain hunian kontemporer. Dewasa ini desain sebuah hunian kontemporer memiliki berbagai macam konsep. Kesesuaian antara konsep bangunan yang melahirkan berbagai macam elemen desain dengan penerapan teori yang mendukung kajian aroma dalam desain bangunan menjadi masalah utama dalam penelitian ini.

Aspek yang menjadi keutamaan dalam penelitian ini adalah kesesuaian antara desain hunian kontemporer beserta dengan seluruh elemen desain bangunan tersebut dengan kajian aroma yang tercipta di dalam ruang huni melalui implementasi desain arsitektur, pengaplikasian tanaman, atau pertimbangan lain yang mendukung.

Adapun yang menjadi tujuan dari penelitian ini adalah untuk membawa kembali paradigma desain dalam arsitektur. Bahwa sebuah desain arsitektur yang baik adalah desain yang terlahir dari sensitifitas panca indera manusia. Hal ini memiliki tujuan supaya segala bentuk aktivitas manusia dapat berlangsung secara nyaman sehingga fungsi daripada ruang guna dapat maksimal.

Dalam penelitian ini tujuan utama adalah pembahasan tentang aroma yang merupakan korelasi daripada indera penciuman. Bagaimana kenyamanan ruang akan tercipta tidak hanya berdasar pada pertimbangan visual semata tetapi juga kajian dari indera penciuman manusia. Kebahagiaan dan kenyamanan dapat tercapai dari aroma yang baik pada sebuah ruang guna. Sedangkan keempat indera yang lain akah dibahas pada penelitian berikutnya.

Manfaat dari penelitian ini diharapkan dapat menjadi salah satu referensi dalam menciptakan desain hunian yang nyaman untuk digunakan dan memberikan kedamaian antara alam dengan penggunanya. Kajian tersebut lebih menitik beratkan pada pertimbangan indra penciuman yang juga berperan dalam menciptakan sebuah desain hunian kontemporer.

\section{METODE PENELITIAN}

Dalam penelitian ini, metode yang akan digunakan adalah deskriptif kualitatif yang artinya penelitian memberikan gambaran secara cermat mengenai keadaan dan gejala yang terjadi (Koentjaraningrat, 1993; 89). Ciri-ciri dari penelitian dengan metode kualitatif menurut Bogden dan Biklen (1992; 27-29) antara lain:

1. Qualitative research has the natural setting as the direct source of data, and the researcher is the key instrument.

2. Qualitative research is descriptive.

3. Qualitative researchers are concerned with process as well as product.

4. Qualitative researchers tend to analyze their data inductively.

Metode kualitatif yang digunakan dalam penelitian ini akan membantu untuk menjawab permasalahan yang terfokus pada fenomena dari objek penelitian yaitu hunian kontemporer dengan objek penelitian BSB City Semarang. Objek dari penelitian ini berlokasi di Perumahan BSB City Mijen Semarang. Adapun yang menjadi alasan tentang penentuan lokasi ini dikarenakan BSB City merupakan sebuah kawasan berkembang di ujung Kota Semarang. Target pasar dari pengembang ini adalah masyarakat berusia muda yang masih berkembang. Terdapat berbagai fasilitas baru beserta dengan pusat-pusat keramaian baru yang menjadikan BSB menjadi kawasan baru hunian di Semarang. Latar belakang ini sesuai dengan desain penelitian yang ingin melihat lebih dalam tentang bagaimana konsep desain hunian baru, apakah tetap sesuai dengan kaidahkaidah yang menitikberatkan panca indera manusia dalam mendukung fungsi ruang terutama yang berkaitan dengan aroma (indera penciuman).

Populasi yang menjadi objek penelitian ini adalah sebuah hunian yang berlokasi di Cluster Naraya. Cluster ini masuk di dalam rancangan pengembangan BSB tahun 2017. Pengamatan dilakukan pada satu objek secara detail dengan memperhatikan setiap elemen bangunan yang berkaitan dengan teori aroma.

Penelitian tentang aroma merupakan turunan dari penelitian-penelitian lampau yang sudah dilakukan. Tetap ber- 
muara pada konsentrasi arsitektur hijau dengan panduan teori GAIA.

Teori GAIA dijelaskan di dalam Natural House Book karya David Pearson dan salah satu kajian yang dipertimbangkan adalah pentingnya aroma (indera penciuman) dalam pertimbangan desain arsitektural. Bagaimana menghadirkan sebuah kualitas ruang huni sehingga dapat berfungsi secara maksimal dalam menampung aktivitas manusia di dalamnya.

Metode penelitian yang digunakan adalah studi kualitatif dengan pendekatan observasi, wawancara, dan literatur. Metode penelitian ini menggunakan metode rasionalis kualitatif. Metode rasionalis kualitatif memiliki ciri fenomena yang terjadi di lapangan merupakan data utama yang harus diamati oleh peneliti yang berperan sebagai instrument utama. Fenomena hasil data pengamatan objek penelitian di lapangan akan diperkuat dengan wawancara terhadap arsitek perencaan BSB City Semarang.

\section{ANALISIS DAN INTEPRETASI DATA}

\section{Hipotesa GAIA}

Kajian tentang pentingnya aroma di dalam pertimbangan desain hunian bermuara pada teori Hipotesis GAIA. Hipotesis GAIA dicetuskan oleh James Lovelock, ilmuwan yang berasal dari Inggris. James adalah seorang ilmuwan independen pada bidang ilmu bumi, lingkungan, dan kimia.

Hipotesis GAIA adalah sebuah pemikiran yang menyatakan bahwa semua komponen yang ada di bumi akan saling menyatu untuk membentuk sebuah interaksi yang akan menjaga stabilitas dan keseimbangan keadaan bumi.

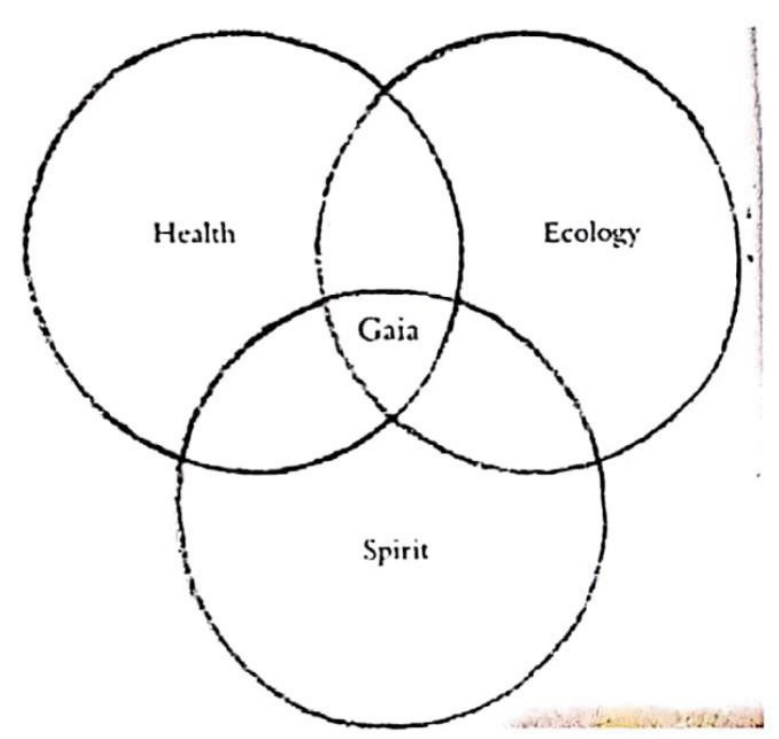

Gambar 1. Diagram Hipotesis GAIA

(Sumber: dokumentasi pribadi)
Hipotesis GAIA menganggap bahwa bumi adalah sebuah organisme tunggal yang memiliki kehidupan.

Argumen lain menurut James Lovelock, GAIA merupakan sebuah hipotesis yang berpandangan bahwa bumi sejatinya adalah sebuah organisme. Maka dari itu dapat diartikan bahwa GAIA House Charter adalah pedoman tentang sebuah bangunan atau rumah yang dirancang dengan memperhatikan faktor bumi.

Dalam hipotesa GAIA, terdapat 3 elemen penting yang perlu diperhatikan untuk mencapai sebuah desain arsitektur yang baik bagi kehidupan. Ketiga elemen tersebut antara lain kesehatan jasmani, jiwa dan alam. Perpaduan antara ketiga elemen tersebut bertujuan supaya setiap desain bangunan yang dibuat mampu menghadirkan nilai prioritas kehidupan dalam arsitektur yakni Hunian yang mampu dijadikan sebagai ruang harmoni dan penyembuhan bagi fisik dan jiwa penggunanya. Sejalan dengan pola pikir hipotesa GAIA, salah satu cara untuk mendukung terciptanya harmoni kehidupan di dalam bangunan adalah dengan menguatkan kembali unsur aroma di dalam bangunan. Aroma atau scent dalam Bahasa inggris merupakan salah satu kajian yang semestinya juga diperhatikan di dalam ilmu arsitektur. Aroma sangat berkorelasi dengan indra penciuman yang merupakan indra tertajam yang dimiliki oleh manusia. Pengolahan desain bangunan yang mampu memperhatikan unsur aroma baik di dalam maupun di luar ruangan akan mendukung keharmonisan hubungan antara bangunan dengan penggunannya.

\section{Lokasi}

Cluster Naraya yang menjadi objek penelitian memiliki 3 macam tipe hunian yang dipasarkan. Sedangkan objek yang menjadi fokus penelitian adalah hunian yang memiliki luas lahan $120 \mathrm{~m}^{2}$. Tipologi bangunan memiliki 2 lantai fungsi dengan konsep desain yang cukup unik. Mengapa unik karena di lantai dasar hanya terdapat ruang guna yang bersifat publik, sedangkan lantai 1 berisi ruang-ruang privat.

Pada desain hunian lantai 1 terdapat 2 kamar tidur yang bersebalahan diakomodasi dengan sebuah kamar mandi. Kedua kamar tidur memperoleh bukaan yang cukup besar menghadap ke arah belakang rumah (taman).

Desain hunian yang baik adalah desain yang berlandaskan pada pertimbangan sensifitas panca indera manusia. Terdapat dua poin kajian yang dapat diimplementasikan dalam mendukung terciptanya aroma yang baik di dalam ruang. Kajian dengan pendekatan desain bangunan secara pasif dan kajian dengan pendekatan bahan-bahan alami.

\section{Passive Design}

Desain pasif adalah sebuah langkah yang dilakukan untuk mengoptimalkan kinerja alam dan lingkungan sekitar dalam proses merumuskan desain ruang (hunian). Seluruh 


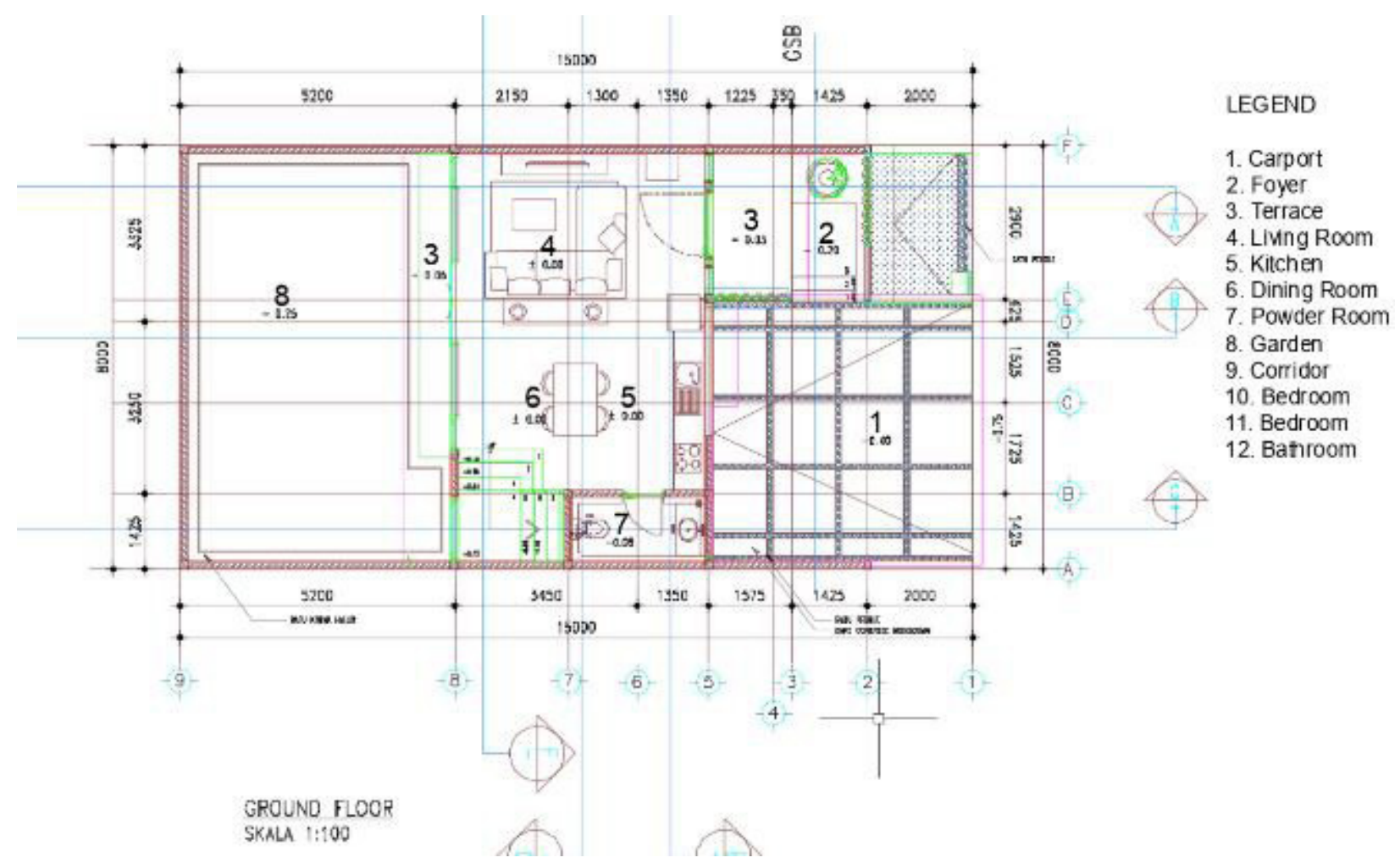

Gambar 2. Denah Lantai Dasar (Sumber: dokumentasi pengembang)

hasil desain memiliki orientasi untuk mengoptimalkan sistem pencahayaan dan penghawaan alami dalam ruang. Pendekatan teknik dan strategi desain diperlukan untuk mendapatkan desain pasif yang optimal.

Desain pasif yang mendukung tercapainya kajian tentang aroma dapat dirumuskan dalam beberapa poin pengamatan dalam penelitian ini antara lain:

\section{Bukaan sebagai media sirkulasi udara dan aroma}

Aroma baik yang tercipta diharapkan dapat membantu tercapainya fungsi ruang guna secara maksimal. Aroma tersebut dapat dihirup dan memberikan efek yang signifikan melalui pergerakan udara dalam ruang. Dibutuhkan pergerakan udara yang baik di setiap ruang sehingga setiap ruang dapat berfungsi secara maksimal.

Bukaan lebar terdapat pada hunian yang menjadi objek penelitian. Bukaan tersebut memungkinkan terjadinya sirkulasi yang sangat baik antara ruang luar yang menjadi sumber pergerakan udara dengan ruang dalam bangunan.

\section{Cross Ventilation}

Ventilasi silang adalah sebuah ilmu fisika bangunan yang kerap diterapkan dalam bangunan dengan tujuan untuk menciptakan pergerakan udara dalam bangunan. Pergerakan udara dalam bangunan ini diharapkan dapat sekaligus membantu persebaran aroma baik di dalam bangunan.

Lantas bagaimanakah kajian ventilasi silang pada objek penelitian?
Sistem ventilasi silang juga terdapat pada desain ruang fungsi yang terdapat pada objek penelitian. Hal ini menandakan bahwa desain perencanaan sudah mempertimbangkan aspek terjadinya pergerakan udara yang mendukung terciptanya aroma yang baik bagi ruangan. Bukaan yang terletak berseberangan pada lantai dasar bangunan memungkinkan terjadinya ventilasi silang. Dengan luas bukaan yang besar dibandingkan dengan luas ruangan yang lebih kecil, maka proses pergerakan angin dapat terjadi dalam skala yang cukup besar.

Media Tanam Dan Hubungannya Dengan Ruang Guna Segala bentuk perencanaan desain elemen bangunan tidak akan signifikan fungsinya apabila sumber daripada aroma yang baik tidak menjadi pertimbangan dalam desain. Media tanam merupakan kaidah pokok yang wajib diaplikasikan pada desain hunian sebagai wadah berkembangnya sumber aroma alami berupa tanaman.

Gambar 6 menunjukan bahwa media tanam pada objek penelitian sudah terakomodasi dalam desain. Media tanam yang cukup luas dan terletak persis bersebelahan dengan ruang utama sangat menguntungkan bagi pengguna. Hal ini dikarenakan kemungkinan terciptanya aroma yang baik yang dapat dinikmati oleh penggunakan bangunan di ruang utama sangat besar.

\section{Pendekatan Bahan-Bahan Alami}

Untuk menghindari bau tidak sedap di dalam bangunan yang bertujuan untuk menciptakan lingkungan yang memiliki aroma alami langkah pertama adalah dengan menghil- 


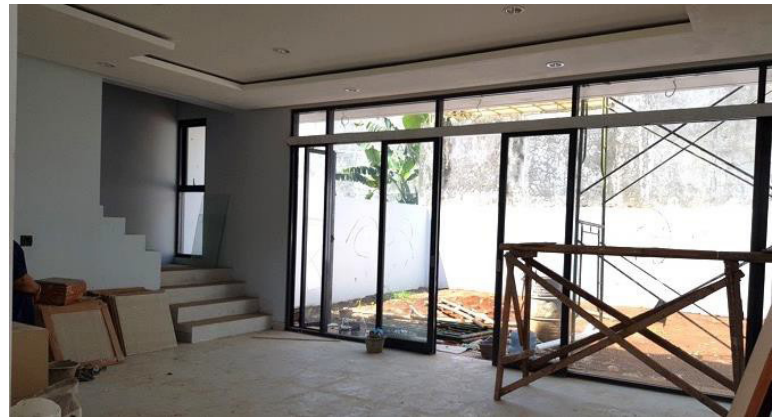

Gambar 3. Bukaan Lantai Dasar (Sumber: dokumentasi pribadi)

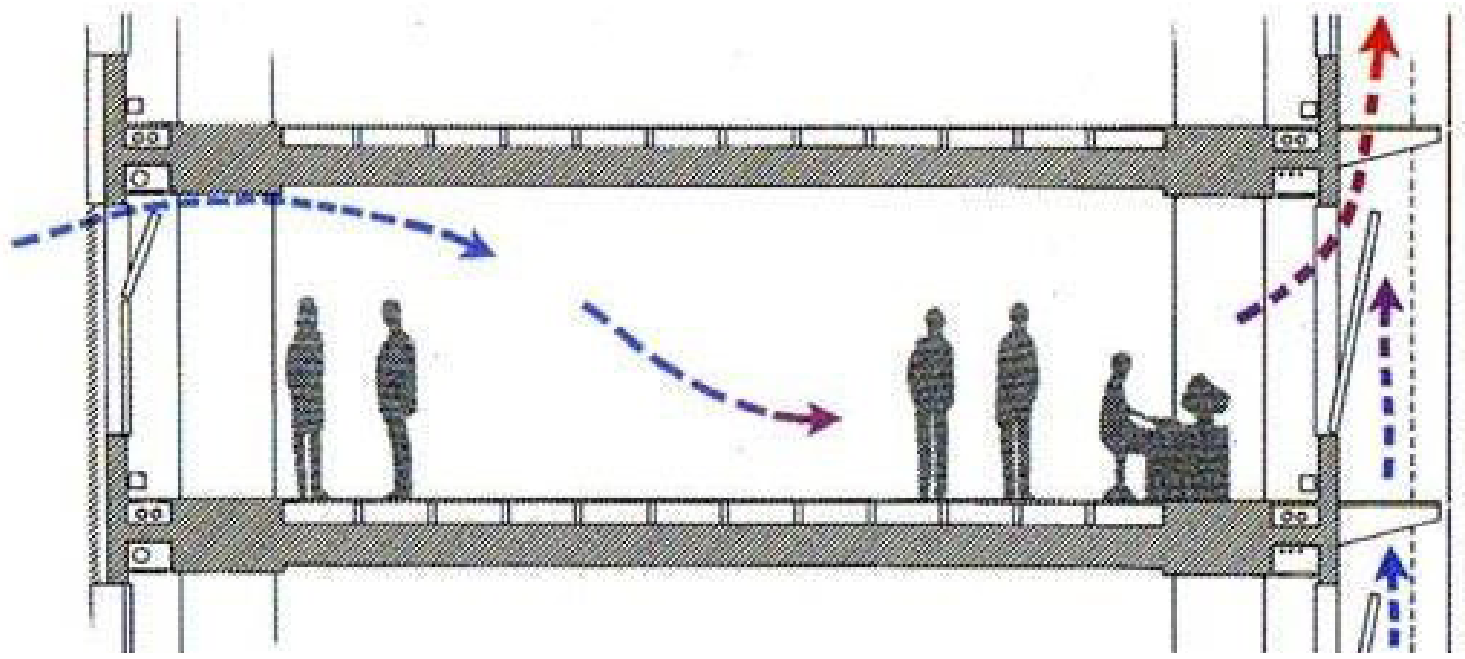

Gambar 5. Cross Ventilation (Sumber: https://www.apartmenttherapy.com)

Gambar 4. Ventilasi Silang pada Bangunan (Sumber: dokumentasi pribadi)

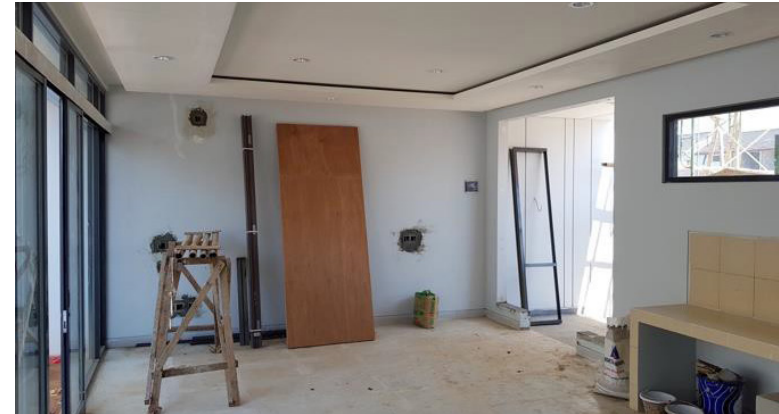

alami berupa bunga dan tanaman juga bisa menjadi bahan pertimbangan untuk menghadirkan aroma ruangan yang mendukung kenyamanan pengguna ruang. Sejak jaman peradaban Yunani dan Romawi kuno ramuan bahan-bahan alami menjadi cara untuk menghadirkan aroma yang baik di sekitar bangunan. Dengan meletakan dan menumbuhkan tanaman, bunga di sekitar bukaan jendela, pintu, dan taman yang dekat dengan ruang guna, meletakkan kayu aromatik seperti kayu pohon cemara, dan cendana merupakan cara-cara yang bisa dilakukan untuk mendukung terciptanya aroma yang sedap bagi harmonisasi jiwa, fisik, dan alam lingkungan sekitar.

Dewasa ini sebagai upaya untuk menghadirkan aroma yang baik di dalam ruang, manusia sangat sering bertumpu pada bahan-bahan kimiawi. Tanpa disadari, penggunaan bahan kimiawi ini merupakan sebuah langkah pengkhianatan terhadap alam. Kembali lagi apabila kita melihat hipotesa GAIA, sejatinya antara bangunan dengan alam dan penggunanya memiliki hubungan yang harmonis. Tidak ada unsur kimiawi yang menjadi kajian di dalam hipotesa tersebut.

Berikutnya adalah menentukan jenis-jenis tanaman yang dapat mendukung terciptanya aroma yang baik secara alami. 


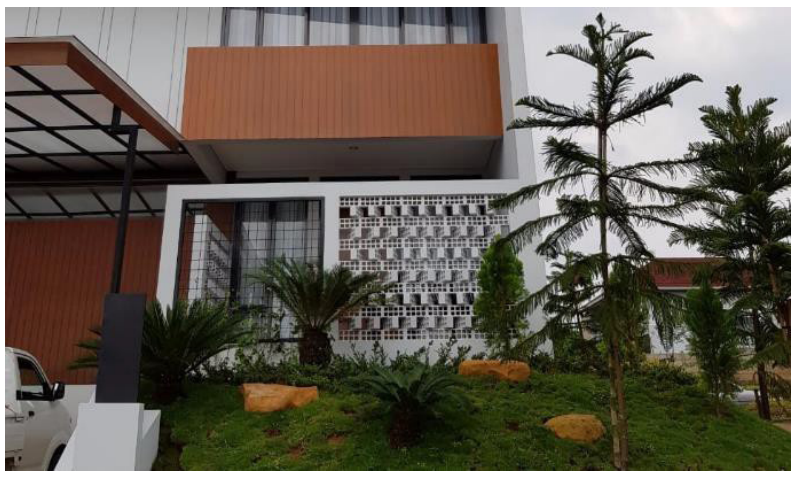

Gambar 6. Media Tanam Pada Ruang Huni (Sumber: dokumentasi pribadi)

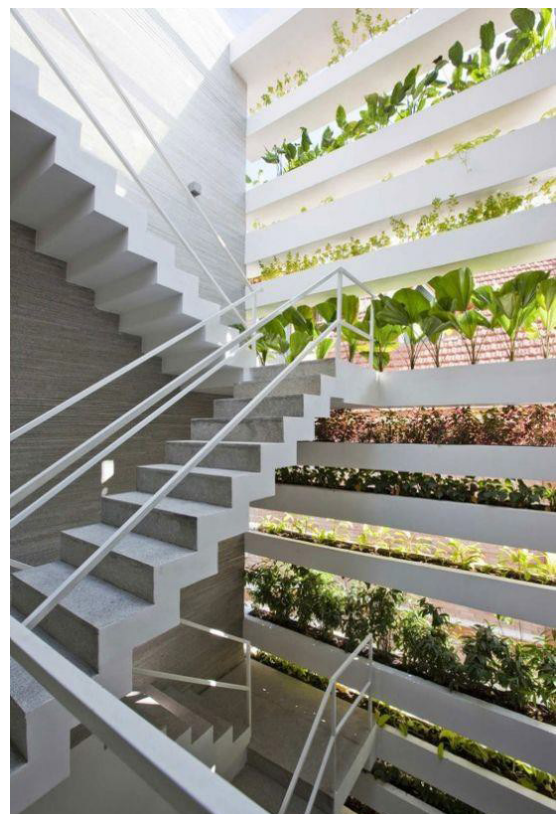

Gambar 7. Aplikasi Bahan Alami Pada Interior

1. Kesembukan

2. Tenggulun

3. Celagi

\section{SIMPULAN}

Berdasarkan kajian dari teori dan hasil observasi diobjek penelitian dapat disimpulkan bahwa perencanaan desain hunian kontemporer pada objek penelitian yang berlokasi di perumahan BSB Semarang, telah mempertimbangkan kajian aroma. Kajian aroma pada objek penelitian diakomodasi melalui desain bukaan yang mengoptimalkan terjadinya penghawaan alami melalui ventilasi silang. Maka dari itu pertimbangan tentang pemilihan jenis tanaman mestinya menjadi bahan pertimbangan yang cukup vital. Hal ini dimaksudkan supaya kajian aroma benar-benar dapat terealisasi di dalam ruang guna dan meningkatkan aktivitas penggunanya.

Kesimpulan akhir dari penelitian ini adalah pertimbangan desain yang mendukung kajian aroma sudah optimal, namun perlu tindak lanjut berupa pemilihan jenis tanaman

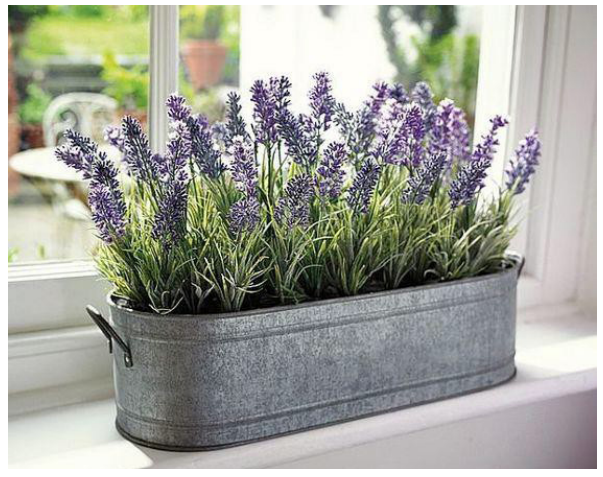

Gambar 8. Aplikasi Bahan Alami Pada Interior

alami yang mendukung terciptanya aroma yang baik.

\section{DAFTAR RUJUKAN}

Anink, D., Boonstra, Chiel, Mark, and John. (1996). Handbook of Sustainable Building. James \& James, London.

Bogdan, R. C., \& Biklen, S. K. (1992). Qualitative research for education. An introduction to theory and methods., MA: Allyn \& Bacon. Carpenter, P. L., T.D. Boston

Koentjaraningrat. (1993). Metode-metode Penelitian Masyarakat. PT. Gramedia Pustaka Utama. Jakarta.

Pearson, David. (1998). The New Natural House Book. Fireside, New York. 